\title{
MAKNA KEBERKAHAN AL-QUR'AN (Analisis Terhadap QS. şād/38:29)
}

\author{
RUSLAN \\ Program Studi Ilmu Al-Qur'an dan Tafsir \\ Fakultas Ushuluddin dan Dakwah IAIN Bone \\ Email : ruslanssangaji@gmail.com.
}

\begin{abstract}
Abstrak
Tulisan ini memaparkan tentang makna keberkahan al-Qur'an yang berfokus pada analisis QS. Sad/38:29. Ada tiga yang akan dijawab. Pertama, bagaimana gambaran ayat tentang keberkahan al-qur'an. Kedua, bagaimana analisis ayat QS. Sad/38:29. Ketiga, bagaimana bentuk keberkahan al-Qur'an. Masalah ini dijawab dengan menggunakan metode tafsir dengan cara mengemukakan seluruh ayat yang berkaitan tentang keberkahan al-qur'an kemudian memfokuskan pada salah satu ayat yang memang menjadi objek analisis. Ayat tersebut dianalisis dengan menggunakan pendekatan linguistik dan ilmu tafsir. Tulisan ini menghasilkan suatu temuan bahwa keberkahan alqur'an dapat diraih melalui dua cara. Pertama, melalui pembacaan ayat-ayat al-qur'an itu sendiri yang biasa dilakukan secara tilawah, atau qira'ah termasuk didalamnya membacanya untuk sebagai sebuah harapan atau doa tertentu dan, yang kedua adalah melalui cara pendalaman pada makna atau maksud ayat dalam rangka mengetahui orientasi makna ayat al-Qur'an secara komprehensip atau dengan istilah tadabbur. Melalui tadabbur pada al-Qur'an, manusia dapat menemukan banyak petunjuk yang dapat bermanfaat bagi manusia dan kehidupannya.
\end{abstract}

Kata kunci: Berkah, Al-Qur'an, Tadabbur.

\section{PENDAHULUAN}

Sisi-sisi al-Qur'an selalu menjadi perbincangan menarik, termasuk interpretasi al-Qur'an itu sendiri. Tidak hanya bagi orang yang telah percaya atas keberadaan wahyu yang pernah turun kepada nabi saw., tetapi termasuk bagi mereka yang tidak beriman kepada wahyu al-qur'an (misalnya orientalis). ${ }^{1}$ Banyak pakar atau sarjana telah menulis interpretasi al-qur'an, tetapi hal yang mereka tulis dianggap 2006), h. 1

${ }^{1}$ M. Nur Kholis Setiawan, Al-Qur'an Kitab Sastra Terbesar (Yogyakarta: eLSAQ Press, 
belum final. Derajat pemahaman mereka tergolong relatif dan tidak bisa mencapai derajat absolut sehingga kemunculan literasi yang berbicara mengenai al-qur'an pun semakin banyak dengan berbagai pendekatannya. Sesuatu yang mengerankan bagi sejumlah pihak atas keunikan al-qur'an, karena seakan tidak pernah habisnya dikaji dan didiskusikan. Pada sisi lain, termasuk keanekaragaman masyarakat Islam dalam mengimplementasikan makna ayat tertentu dalam kehidupan sosialnya (living Qur'an).

Keunikan tentang al-Qur'an juga dapat dilihat dari segi susunan katanya yang tidak sama dengan cara penuturannya dengan kitab samawi lainnya. ${ }^{2}$ Dalam alQur'an ditemukan ayat yang tampak betapa tinggi nilai sastra dan menyaingi karya sastra yang ada. Pada sisi yang lain, al-qur'an juga, dari segi teologis mengandung ayat-ayat yang memiliki kemuliaan atau fadilah yang sifatnya memiliki nilai lebih. Akibat dari inilah, umat Islam sering mensikapi al-Qur'an secara berlebih-lebihan karena berasumsi bahwa al-qur'an punya keberkahan yang dapat ditularkan kepada yang melakukan interaksi dengan al-qur'an itu sendiri. Perlakuan umat Islam ini disebut dengan tabarruk kepada al-qur'an. Istilah tabarruk adakalanya dikaitkan dengan berbagai konteks. Misalnya tabarruk kepada ibadah tertentu yang dilakukan, tabarruk kepada wirid, atau bahkan tabarruk kepada pembacaan barasanji bagi yang percaya untuk suatu tujuan dan lain sebagainya. Tulisan ini tidak akan menguraikan berbagai hal tentang tabarruk melainkan hanya akan fokus pada keberkahan alqur'an.

Sejauh ini tulisan mengenai sisi al-Qur'an termasuk banyak yang bisa kita temukan, akan tetapi kajian dan analisis pada ayat tertentu, misalnya ayat mengenai al-qur'an yang diberkahi bisa dikatakan sangat langka. Sebagai sebuah teks suci, alqur'an, kadangkala di antara manusia ada yang memperlakukan ayat tertentu dengan tujuan mendapatkan keberkahan akan tetapi dengan cara yang irrasional atau sesuatu yang tidak logis. Oleh karena itu, penting melihat dan menganalisis ayat al-Qur'an

\footnotetext{
${ }^{2}$ Quraish Shihab, Mukjizat Al-Quran: Di Tinjau dari Aspek Kebahasaan, Isyarat Ilmiah, dan Pemberitaan Gaib (Bandung: Mizan, 1997), h. 118.
} 
yang mengintrodusir kitab suci al-qur'an sebagai kitab keberkahan (kitabun mubarakun). Melalui kajian seperti ini, dapat ditemukan makna keberkahan yang sebenarnya.

Ayat yang pada umumnya dijadikan sebagai dasar bagi keberkahan alQur'an adalah (Q.S. şād/38:29)



Terjemahnya:

Ini adalah sebuah kitab yang Kami turunkan kepadamu penuh dengan berkah supaya mereka memperhatikan ayat-ayatnya dan supaya mendapat pelajaran orang-orang yang mempunyai pikiran.

Berangkat dari keterangan di atas, maka tulisan ini bertujuan menjawab tiga pertanyaan berikut (a) bagaimana gambaran ayat tentang keberkahan al-qur'an (2) bagaimana analisis ayat pada Q.S. şād/38:29; dan (3) bagaimana wujud atau bentuk keberkahan al-Qur'an.

\section{KAJIAN PUSTAKA}

Ada beberapa tulisan dapat dilihat sehubungan dengan makna keberkahan alqur'an. Abu Aisyah Rahendra Maya, dengan tulisan Perspektif Al-Qur'an tentang Konsep Tadabbur mengatakan bahwa Keberkahan dan kebaikan alquran hanya akan ditemukan setelah melakukan kegiatan tadabbur, perenungan makna-maknanya, dan selalu memikirkan ayat-ayatnya secara berulang-ulang. ${ }^{3}$ Kesimpulan yang dihasilkan oleh Abu Aisyah tentu lahir setelah pengkajiannya secara maudu'i tentang tadabbur dimana makna tadabbur itu sendiri menghendaki banyak melakukan eksplor ayatayat sehingga dapat menemukan pengetahuan baru, yang pada gilirannya menunjukkan bukti adanya keberkahan didalamnya.

\footnotetext{
${ }^{3}$ Abu Aisyah Rahendra Maya, Perspektif Alqur'an tentang Konsep al-Tadabbur. AlTadabbur: Jurnal Ilmu Al-Qur'an dan Tafsir, 2017, 1. 01
} 
Eva Nugraha juga menjelaskan bahwa ada relasi atau hubungan antara hudan-nya al-Qur'an dengan keberkahannya. ${ }^{4}$ Maksudnya, dengan disifatkannya alqur'an sebagai kitab hudan, maka secara tidak langsung didalamnya mencakup banyak kebaikan. Ketika manusia mengambil nilai kebaikan dalam al-qur'an, maka pada dasarnya telah mengambil berkah. Ahmad Kusaeri juga mengatakan bahwa keberkahan memiliki peran penting dalam kehidupan manusia, karena banyak orang yang mencari keberkahan baik dalam segi rezeki, kehidupan dan sebagainya. Oleh karena itu berkah ia defenisikan sebagai segala sesuatu perbuatan dalam kebaikan yang menimbulkan manfaat. Lanjut ia mengatakan bahwa apabila seseorag beriman dan bertakwa kepada Allah dan Rasulnya, maka Allah akan membukakan pintu keberkahan. $^{5}$

Niswatun Hasanah dalam tulisannya yang berjudul keberkahan sebagai formulasi maslahah dalam kehidupan (Refleksi Santri di Pesanteren). Dalam tulisannya ia melihat arti keberkahan dalam praktik ekonomi umat. Ia mengemukakan bahwa tabarruk, mengharap berkah dalam tataran kegiatan ekonomi Islam itu akan mewujudkan manfaat dan berkah baik, di dunia maupun di akhirat. Meskipun keberkahan dapat diformulasikan secara matematis menurutnya, akan tetapi tetap belum bisa menentukan bahwa setiap kegiatan yang kita lakukan itu mendapatkan keberkahan dari Allah swt. karena keberkahan itu merupakan ketentuan dari Allah swt. ${ }^{6}$

Secara keseluruhan informasi literarur di atas, memperlihatkan kajian aspek keberkahan berdasarkan sudut pandang mereka. Akan tetapi tidak ada satupun yang konsen secara spesifik analisisnya pada QS. Q.S. şād/38:29.

\footnotetext{
${ }^{4}$ Eva Nugraha, Ngalap Berkah Al-qur'an: Dampak membaca Al-qur'an Bagi Pembacanya. Ilmu Ushuluddin, 2018, 5.2: 112-131

${ }^{5}$ Ahmad Kusaeri, Berkah dalam Perspektif Al-Qur'an (Kajian tentang Objek yang mendapat keberkahan), Bachelor's Thesis, UIN Syarif Hidayatullah Jakarta, Fakultas Ushuluddin, 2017.

${ }^{6}$ Niswatun Hasanah, Keberkahan sebagai Formulasi Maslahah dalam Kehidupan (Refleksi Santri di Pesantren), Qiema, 2018, 4.2: 129-142.
} 


\section{METODE PENELITIAN}

Tulisan ini merupakan hasil kajian yang menggunakan penelitian kepustakaan (library research) yang bersifat kualitatif (qualitative research). Jenis penelitiannya adalah deskriptif verifikatif. Penelitian ini dilaksanakan untuk menggambarkan dan menjelaskan konsep Alquran tentang keberkahan dengan menggunakan pendekatan ilmu tafsir. Pendekatan ilmu tafsir disini adalah pendekatan yang menggunakan lebih banyak kitab tafsir dalam mendeskripsikan dan menganalisis data ayat. Kemudian, metode yang digunakan adalah metode atau cara kerja tafsir mauḍ̄' '̄y (tematik) seperti yang telah dikonstruksi oleh al-Farmāwiy.

Sumber data untuk keperluan analisis guna menginterpretasi data primer, dibutuhkan sumber data sekunder, antara lain: (1) Kitab-kitab hadis dan tafsir yang memuat sebuah kajian yang relevan dengan permasalahan yang diangkat dalam penelitian ini. (2) Buku-buku yang menguraikan pengetahuan tentang seluk beluk Alquran, dengan kata lain ulumul qur'an. (3) Kepustakaan yang membahas berbagai masalah yang berkenaan dengan Alquran sebagai kitab berkah.(4) Sejumlah ensiklopedia dan kamus yang menguraikan hal-hal yang ada kaitannya dengan keberkahan itu sendiri. Misalnya antara lain : Ensiklopedia Mukjizat Alquran dan Hadis yang disusun oleh Hisham Thalbah (et al.), al-Mufradāt fĩ Garĩb al-Qur'ān karya al-Rāgib al-Asfahān̄̄, al-Mu’jam al-Mufahras li Alfāz al-Qur'ān al-Karīm karya Muhammad Fu'ād Abd al-Bāqī, Mu’jam al-Maqāyis fĩ al-Lugah karya Abū alHusain Ahmad bin Fāris bin Zakariya, Lisān al- 'Arab karya Ibnu Manẓūr.

\section{HASIL PENELITIAN DAN PEMBAHASAN}

\section{Gambaran Ayat tentang Keberkahan al-Qur'an}

Terdapat empat ayat yang menyebut keberkahan al-qur'an dalam bentuk masdar:

1. QS. Al-an'am/6:92 dan 155: 




Terjemahnya:

Dan ini Al-Qur'an adalah kitab yang telah Kami turunkan, yang diberkati, membenarkan kitab-kitab yang (diturunkan) sebelumnya dan agar kamu member peringatan kepada (penduduk) Ummul Qura (Mekah) dan orangorang yang diluar lingkungannya, orang-orang beriman kepada adanya kehidupan akhirat tentu beriman kepadanya (Alquran) dan mereka selalu memelihara shalatnya.

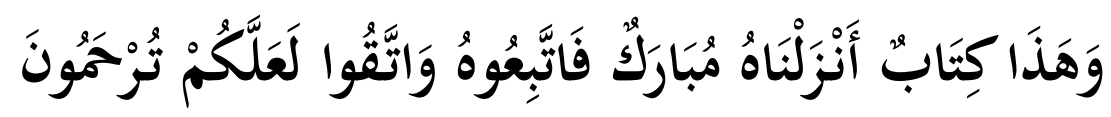

Terjemahnya:

Dan Alquran ini adalah kitab yang Kami turunkan, yang diberkati, maka ikutilah dia dan bertakwalah agar kamu diberi rahmat.

2. QS. Al-anbiya'/21:50

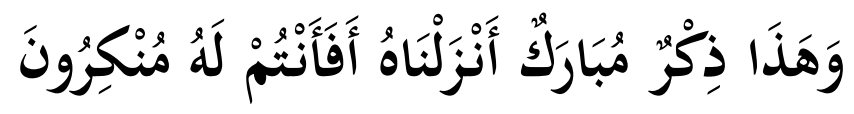

Terjemahnya:

Dan Alquran ini adalah suatu kitab peringatan yang mempunyai berkah yang telah Kami turunkan, maka mengapakah kamu mengingkarinya?

3. QS. Sad/ :29

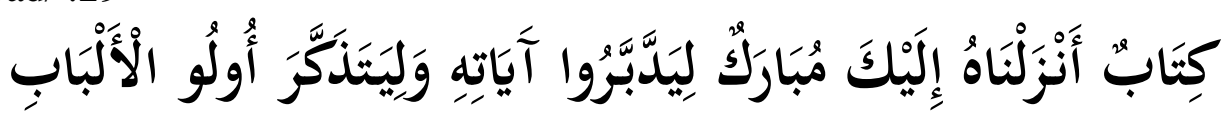

Terjemahnya:

Dan Ini adalah sebuah kitab yang Kami turunkan kepadamu penuh dengan berkah supaya mereka memperhatikan ayat-ayatnya dan supaya mendapat pelajaran orang-orang yang mempunyai pikiran. 
Analisis Ayat QS. Q.S. şād/38:29

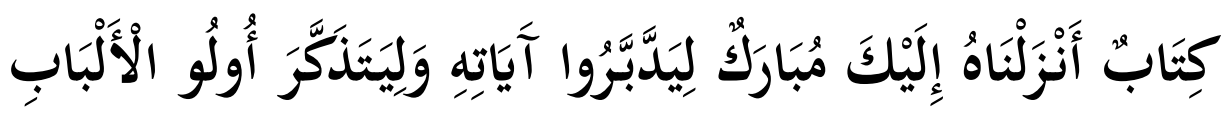

Sebelum mengkaji secara mendalam ayat tersebut, perlu lebih dahulu ditelusuri makna kata berkah. Istilah berkah berasal dari bahasa Arab, برو berakar kata dari huruf $b, r$ dan $k$ yang pada awalnya bermakna "dada unta", lalu kemudian kata itu digunakan dalam konteks dan makna lain. Al-Ragib al-Asfahani menjelaskan bahwa kata baraka kemudian menjadi al-barakah mempunyai makna ثبوت الخير الالههي لtetapnya suatu kebaikan ilahi pada sesuatu”7 kata itu seakar dengan kata albirkah yang berarti "kolam" sehingga maknanya dapat dianalogikan seperti yang dikemukakan oleh al-Asfahani yang mengatakan bahwa "dikatakan demikian, karena tetapnya suatu kebaikan pada sesuatu sama halnya dengan tetapnya air dalam suatu kolam". Dengan demikian, keberkahan itu adalah bersifat tetap dan merupakan pemberian Allah yang memiliki nilai kebaikan. Secara mendasar "berkah" dan "pemberian berkah" hanya berasal, milik dan hak Allah swt.

Al-Khalil mengatakan berkah bermakna "bertambah dan tumbuh serta berkembang". 8 Dari makna tersebut dapat dipahami bahwa berkah adalah sesuatu kebaikan yang akan tumbuh dan tetap pada sesuatu. Penggunaan istilah berkah seringkali ditemukan dalam Alquran, termasuk hubungannya kepada Alquran. Dalam kaitannya dengan Alquran, keberkahan pada umumnya disebut dengan term mubārak. ${ }^{9}$ Alquran menyebutnya dalam empat ayat, namun pada tiga surah yang berbeda. Dua ayat pada surah al-an'ām yakni ayat 92 dan 155, masing-masing satu ayat pada surah al-anbiyā' yaitu ayat 50 dan surah şād yaitu ayat 29 .

\footnotetext{
${ }^{7}$ Al-Rāgib al-Asfahānĩy, Mufradāt Fi Garĩb al-Qur'ān, (Bairut: Dar al-M'rifah, t.th.), h. 54

${ }^{8}$ Abū Muhammad 'Abd al-Haq bin Galĩb bin 'Abd al-Rahmān ibn Tamām ibn 'Atiyah alMahāriby, Al-Muharrir al-Waĩiz, Juz 2 ( t.tp: Mauqi’ al-Tafasir, t.th.), h. 497

${ }^{9}$ Muhammad Fu'ad abd al-Baqi, al-Mu'jam al-Mufahras li Alfaz al-Qur'an al-Karim (Indonesia: Maktabah Dahlan, t.th.), h. 150
} 
Kembali kepada ayat di atas, Ibnu 'Asyur memahami frase kitābun anzalnāhu ilaika mubārakun (sebuah kitab yang Kami turunkan kepadamu penuh dengan berkah) dengan maksud bahwa tiap-tiap ayat Alquran punya berkah. Bila demikian pemahamannya, maka dari enam ribuan ayat lebih kurang, masing-masing mengandung berkah atau ada nilai kebaikan yang telah ditetapkan oleh Allah di dalam setiap ayat. Oleh karena itu, tidak mengherankan bila manusia dalam berinteraksi dengan al-qur'an, masing-masing punya cara dan pendekatan dengan maksud mengharap keberkahan. Inilah nanti sehingga banyak orang melakukan sesuatu yang berkaitan dengan al-Qur'an dengan harapan macam-macam maksud dan tujuannya yang disebut dengan bertabarruk dengan al-Qur'an.

Selanjutnya, keberkahan al-Qur'an karena memiliki manfaat serta memberi petunjuk kebaikan bagi manusia dan menghindarkannya dari bentuk kejahatan serta kerusakan. ${ }^{10}$ Pernyataan ini sejalan dengan pendapat Eva Nugraha juga yang telah menilai bahwa ada relasi atau hubungan antara hudan-nya al-Qur'an dengan keberkahan. ${ }^{11}$ Pendapat ini semakin memperkuat pemahaman bahwa manusia yang menjadikan al-Qur'an sebagai pedoman hidup, maka hidupnya akan penuh dengan keberkahan. Makna keberkahan al-Qur'an bagi al-Biqā'i adalah kitab yang selamalamanya akan menyimpan kebaikan dan manfaat dan tidak akan ada yang bisa mengubahnya. ${ }^{12}$ Al-Qur'an disebut sebagai kitab mengandung berkah yang berarti mengandung banyak manfaat dan kebaikan. ${ }^{13}$ Dalam tafsir al-Muntakhib dijelaskan

\footnotetext{
${ }^{10}$ Muhammad Tāhir Ibnu 'Asyūr, Muhammad Tahir Ibnu 'Asyūr, Tafsĩr al-Tahrĩ wa alTanwĩr, Jilid XII, (Tunisia: al-Dār Tunĩsiyyah li al-Nasyr, 1984), h. 221

${ }^{11}$ Eva Nugraha, Ngalap Berkah Al-Qur'an: Dampak Membaca Al-Qur'an Bagi Pembacanya. Ilmu Ushuluddin, 2018, 5.2: 112-131.

${ }^{12} \mathrm{Ibrāhim}$ bin 'Umar bin Hasan al-Ribāt bin 'Ali bin Abi Bakr al-Biqā'i, Nazm al-Durar Fĩ Tanāsub al-Āyāt wa al-suwar, Juz VII, dalam al-Maktabah al-Syāmilah, http//www. altafsir.com, h. 192.

${ }^{13}$ Al-Qurthuby, al-Jāmi' li Ahkām al-Qur'ān, Juz I (t.t.: Maūqi' al-Tafāsir, t.th), h. 2059.
} 
bahwa al-Qur'an disebut berberkah karena mengandung kebaikan ilahi yang bermanfaat baik dalam kehidupan beragama, maupun untuk kehidupan duniawi. ${ }^{14}$

Dengan demikian, makna berkah atau keberkahan al-Qur'an adalah tersimpannya banyak manfaat yang bersifat tetap dalam al-Qur'an, dan akan tumbuh terus-menerus. Bukti keberkahan al-Qur'an yang dapat dirasakan adalah semakin dipelajari semakin banyak manfaat dan kegunaan yang dapat diperoleh dan tidak habis-habisnya dikaji manusia, baik kalangan muslim sendiri maupun non muslim.

Selanjutnya, yang perlu diuraikan lagi adalah adalah makna liyaddabbarū dan liyatażakkar. Kata liyaddabbarū dipahami sebagai al-tafakkur, yakni memikirkan dan mengamalkan ayat yang sudah diketahui makna dan maksudnya. Pentingnya melakukan tafakkur terhadap Alquran, karena dari segi lafaz terkadang pendekpendek, namun memiliki kandungan yang mendalam. ${ }^{15}$ Pada sisi lain, Muin Salim menjelaskan bahwa makna liyaddabbarū adalah manusia seharusnya mempelajari dan memikirkan makna di belakang atau dibalik ayat-ayat Alquran, karena dari segi bahasa dabar bermakna sesuatu yang ada belakang. ${ }^{16}$ Setelah melakukan tadabbur, selanjutnya melakukan tazakkur. Makna tazakkur adalah mempelajarinya secara mendalam. ${ }^{17}$ Orang yang melakukan proses pendalaman terhadap Alquran disebut sebagai ulul al-bāb. Al-Biqa'i menjelaskan bahwa ulul al-bāb adalah orang yang diberi petunjuk oleh Allah sehingga mampu mengetahui rahasia pengetahuan, baik tentang diri manusia sendiri, maupun yang ada di segala penjuru. Melalui ulul al-bāb

\footnotetext{
${ }^{14}$ Lajnah min 'Ulamā al-Azhar, Tafsĩr al-Muntakhib, Juz I (t.t.: Maūqi' al-Tafāsir, t.th.), h. 236

${ }^{15}$ Muhammad Tahir Ibnu 'Asyūr, Tafsĩr al-Tahrĩr wa al-Tanwĩr, Jilid XII, (Tunisia: al-Dār Tunĩsiyyah li al-Nasyr, 1984), h. 221.

${ }^{16}$ Abd. Muin Salim, Beberapa Aspek Metodologi Tafsir al-Qur'an (Ujung Pandang: Lembaga Studi Kebudayaan Islam, 1990), h. 12

${ }^{17}$ Ibrāhim bin 'Umar bin Hasan al-Ribāt bin 'Ali bin Abi Bakr al-Biqā'i, Nazm al-Durar Fĩ

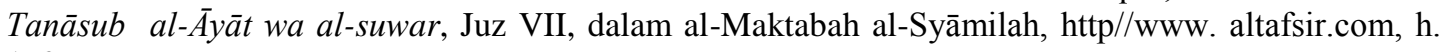
192.
} 
tanda-tanda kekuasaan Tuhan dapat terlihat dan memperjelas bahwa Alquran itu adalah benar (Q.S. Fussilat/41:52-53). ${ }^{18}$

Di samping itu, keberkahan dalam artian 'banyak kebaikan ditebarkan alQuran', memang memberi banyak kontribusi kebaikan kepada umat manusia, baik sebagai individu, maupun sebagai makhluk sosial yang menuntut sebuah kualitas hidup, termasuk salah satu di dalamnya adalah perlunya manusia memperhatikan kualitas makanan yang dikonsumsinya agar menimbulkan keberkahan dalam sisi-sisi kehidupannya.

Al-Qur'an mendidik manusia agar kebutuhan 'perutnya' itu diisi dengan 'halālan tayyiban' (halal dan baik) sebagaimana ditekankan pada Q.S. alBaqarah/2:168:

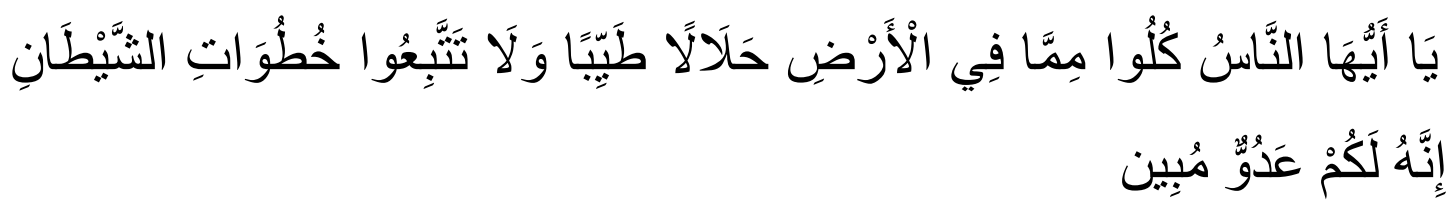

Terjemahnya:

Wahai manusia, makanlah dari (makanan) yang halal dan baik yang terdapat di bumi, dan janganlah kamu mengikuti langkah-langkah setan. Sungguh, setan itu musuh yang nyata bagimu.

Pandangan Quraish Shihab mengenai makanan halal adalah makanan yang tidak haram, yakni yang tidak dilarang oleh agama mengkonsumsinya. Makanan haram ada dua kategorinya, yaitu haram karena zatnya seperti babi, bangkai, dan darah. Sedangkan yang kedua adalah haram karena sesuatu yang bukan zatnya,

\footnotetext{
${ }^{18}$ Ibrāhim bin 'Umar bin Hasan al-Ribāt bin 'Ali bin Abi Bakr al-Biqā'i, Nazm al-Durar Fĩ Tanāsub al-Äyāt wa al-suwar, Juz VII, h. 192.
} 
seperti makanan yang tidak diizinkan pemiliknya untuk dikonsumsi. Makanan halal adalah yang bukan tergolong dari kedua kategori itu. ${ }^{19}$

Sedangkan yang dimaksud tayyiban, menurut Abdurrahman bin Nasir al-Sa'di adalah makanan yang tidak khabĩs. ${ }^{20}$ Bagi tim Lajnah Pentashihan Mushaf Al-Qur'an dalam buku Kesehatan dalam Perspektif Al-Qur'an makna khabĩs tersebut dikembangkan kedalam cakupan makna, makanan yang tidak busuk, kadaluarsa, atau tidak mengandung bakteri atau zat-zat yang membahayakan kesehatan bila dikonsumsi seperti pengawet, pewarna dan penguat rasa. ${ }^{21}$

Demikian contoh-contoh mengenai Alquran disebut sebagai kitab yang mengandung keberkahan. ${ }^{22}$ Allah Swt. memerintahkan manusia agar melakukan tadabbur terhadap isi kitab suci umat Islam ini. ${ }^{23}$ Bukan karena umat Islam hanya dijanjikan pahala dari membacanya, akan tetapi lebih dari itu, mentadabburi alQur'an menjanjikan banyak keberkahan dan nilai manfaat yang sangat sulit diukur secara matematis.

\section{Bentuk Keberkahan Al-Qur'an}

Banyak contoh yang dapat dilihat terkait dengan bentuk bertabarruk dengan al-Qur'an.

1. Membaca ayat al-Qur'an dengan tujuan sebagai do'a

Beberapa riwayat hadis menunjukkan bahwa membaca ayat-ayat tertentu untuk tujuan tertentu dapat digunakan dengan maksud mengharap kebaikan. Misalnya membaca surah al-Mu'awwizatain. Surah ini merupakan dua surah yang mengandung

\footnotetext{
${ }^{19}$ Quraish Shihab, Tafsir al-Mishbah: Pesan, Kesan dan Keserasian Al-Qur'an, Jilid 1 (Jakarta: Lentera Hati, 2002), h. 67.

${ }^{20}$ Abdurrahman bin Nasir al-Sa'di, Taysir al-Karim al-Rahman fi Tafsir al-Kalm al-Mannan, Juz 1 dalam al-Maktabah al-Syamilah (t.t.:Mu'assasah al-Risalah, 2000), h. 80

${ }^{21}$ Tim Penyusun, Kesehatan dalam Perspektif Al-Qur'an, (Jakarta: Lajnah Pentashihan Mushaf Al-Qur'an, 2009), h.378.

${ }^{22}$ Lihat Q.S. al-An'ām/6: 155, Q.S. al-Anbiyā'/21: 50 dan Q.S. şād/38: 29

${ }^{23}$ Lihat Q.S. şād/38: 29
} 
permohonan perlindungan kepada Allah swt., yaitu surah al-falaq dan surah al-nās. Kedua surah itu menggunakan kata " $a$ 'ùzu” yang berarti aku berlindung. Surah ini juga disebut dengan al-Muqasyqisyataini, yang berarti yang membebaskan manusia dari kemunafikan. ${ }^{24}$

Terdapat riwayat hadis yang sumbernya dari Aisyah, ia menyampaikan bahwa bilamana Rasulullah saw. sakit biasanya membacakan dirinya surah alMu'awwizatain, dengan harapan semoga melalui bacaan tersebut dapat memberikan keberkahan.

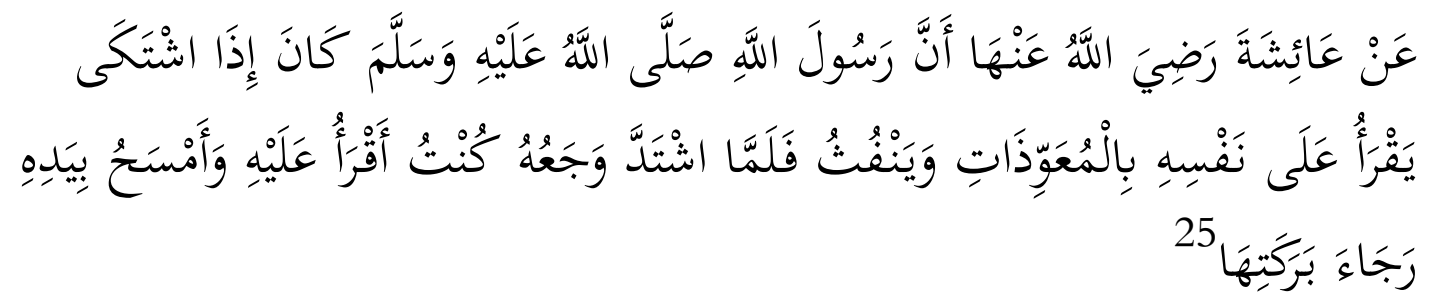

Artinya:

Dari Aisyah r.a., sesungguhnya Rasulullah saw. apabila ada keluhan pada dirinya (sakit), maka ia membacakan dirinya ayat al-mu'awwizat lalu meniupkan. Tatkala sakitnya parah, maka akulah yang membacakanya, aku menyapunya dengan tangan sambil mengharap berkahnya.

Kata 'yanfuśu' dimaknai oleh ulama, yaitu meniup secara lembut tanpa disertai ludah. Riwayat ini, pada satu sisi dijadikan argument perlunya menggunaan ayat Alquran sebagai materi rukiah untuk menjaga kesehatan. ${ }^{26}$

Al-Qur'an memang memberikan keberkahan untuk manusia dalam banyak hal tentang kesehatan. Isyarat-isyarat dari ayat akan pentingnya menjaga hubungan yang kuat antara kesehatan psikospiritual dan kesehatan fisik sungguh banyak dan tidak bisa dinafikan. Misalnya, kondisi ketenangan jiwa, ia merupakan situasi kejiwaan yang sangat ditekankan di samping dapat diraih melalui pelaksanaan

${ }^{24}$ Quraish Shihab, Tafsir Al-Qur'an Al-Karim: Tafsir atas Surat-surat Pendek Berdasarkan Urutan Turunnya Wahyu, (Bandung: Pustaka Hidayah, 1997)., h. 678

${ }^{25}$ Quraish Shihab, Tafsir Al-Qur'an Al-Karim: Tafsir atas Surat-surat ..., Juz IV, h. 2348

${ }^{26} \mathrm{Al}$-Syeikh 'Abd al-'Azĩz al-Sairwan, al-Tibyān bi Syarh mā Ittafaqa 'alaih al-Syaikhān alBukhāri wa Muslim, Juz II (Bairut: Dār al-Rasyĩd, T.th.), h. 533. 
sejumlah praktik keagamaan seperti salat, puasa, juga dapat diraih dalam hal membaca al-Quran. Melalui ritual keagamaan semacam itu, pada hakikatnya memberi pengaruh positif pada diri seseorang.

Keberkahan al-Qur'an memang tidak bisa diukur secara matematik, namun dapat dinilai melalui berbagai kesan dari sejumlah prilaku seseorang yang memperlakukan dan berinteraksi dengan Alquran. Pembacaan al-Qur'an memiliki efek penyembuhan pada tubuh, pikiran dan perasaan. Efek penyembuhan al-Qur'an tidak hanya dari segi maknanya yang memberi kedamaian dan ketenangan, namun juga dari aspek suara dalam membacanya.

Ucapan atau kalimat yang bersumber dari al-Qur'an dan doa mempengaruhi fungsi fisiologis tubuh seperti jantung dan kelenjar tubuh lain. Misalnya resonansi huruf alif berhubungan dengan jantung dan resonansi huruf $y a$ atau sin berhubungan dengan kelenjar pineal di otak. Suara panjang alif memberikan vibrasi yang mempengaruhi jantung dan menstimulasi perasaan akan kekuatan, konsentrasi dan lain-lain. Pembacaan kalimat yang sama dan berulang-ulang diketahui memiliki efek relaksasi. $^{27}$

Bukan hanya kedua surah tersebut diajarkan tetapi masih banyak yang lainnya. Dengan demikian, al-Qur'an memiliki keberkahan dan kemuliaan yang memberi pengaruh positif pada jasmani dan ruhani manusia, baik pada saat membacanya atau mendengarkannya.

2. Mengambil berkah melalui proses pendalaman atau tadabbur

Seperti yang disebutkan sebelumnya, tadabbur kepada al-qur'an, pada hakikatnya juga melakukan cara meraih banyak kebaikan atau keberkahan dalam alQur'an. Terdapat dua ayat mengisyaratkan kepada manusia sebagai tantangan agar al-Qur'an seyogyanya dikaji maknanya/maksudnya secara mendalam (tadabbur), yaitu QS. Al-Nisa/4:82 dan QS. Muhammad/47:24. Mentadabburi al-Qur'an melalui

\footnotetext{
${ }^{27}$ Aliah B. Purwakania Hasan, Pengantar Psikologi Kesehatan Islami ( Jakarta: Rajawali Pers, 2008), h. 130
} 
kegiatan pembelajaran untuk menemukan maksud suatu ayat dipandang akan memnghasilkan kebaikan-kebaikan atau berkah. Hal ini dapat pula dilihat pada satu hadis yang diriwatarkan oleh Imam Muslim tentang betapa banyak berkah atau kebaikan yang diperoleh manusia bila mempelajari al-Qur'an:

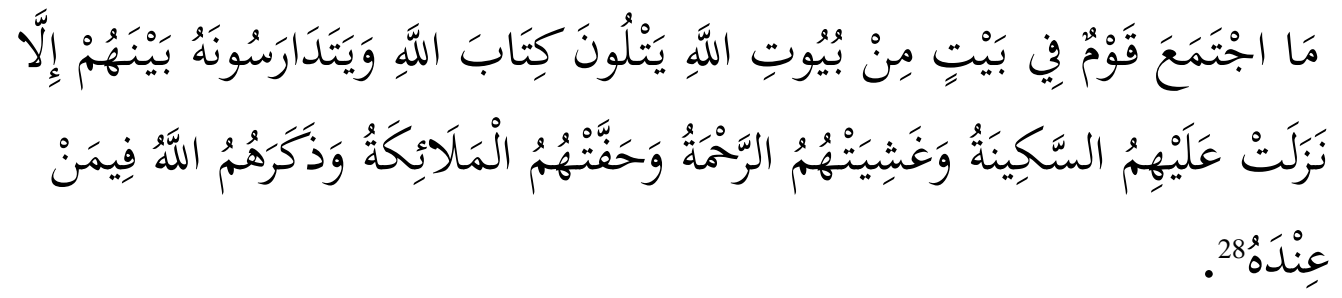

Artinya:

Tidaklah suatu kaum berkumpul di salah satu rumah Allah untuk membaca Kitabullah (Al-Qur`an) dan mereka saling mempelajarinya kecuali sakinah (ketenangan) akan turun kepada mereka, majlis mereka penuh dengan rahmat dan para malaikat akan mengelilingi (majlis) mereka serta Allah akan menyebutkan mereka (orang yang ada dalam majlis tersebut) di hadapan para malaikat yang di sisi-Nya.

Terkait dengan hal tersebut, Allah juga mengharapkan manusia melalui tadabbur, mereka dapat membiasakan jiwa atau hatinya bahkan wawasannya terbuka menerima kebenaran. Dari sini pula dapat dipahami bahwa manusia yang terbiasa mentadabburi al-Qur'an, pada dasarnya, hati, jiwa, dan wawasannya akan bertambah luas seiring dengan bertambahnya ilmu pengetahuan yang mereka temukan.

Dengan demikian, dalam setiap aktivitas manusia, yang sering diharapkan datang adalah keberkahan. Nilai keberkahan sulit dihitung, karena boleh jadi kebaikan-kebaikan yang dihasilkan dalam suatu aktivitas berkaitan dengan nilai transendental, karena yang menghendaki keberkahan itu ada adalah Allah swt.,sekalipun manusia tetap harus berusaha untuk mendapatkannya. Manusia mengharapkan dan mencari keberkahan pada semua sisi kehidupannya, mulai dari

\footnotetext{
${ }^{28}$ Al-Imam Abi al-Husain Muslim Ibn al-Hajjaj al-Qusyairiy al-Naisabury, Sahih Muslim, Juz XIII ( Riyadh: Dar al-Kutub li al-Thaba'ah wa al-Nasyr wa al-Tauzi, 1996), h. 212
} 
manusia terbangun sampai tidur kembali keberkahan hidup selalu menjadi dambaan, termasuk dalam segala bentuk usahanya dalam mencari rezki.

Surah sad ayat 29 mengajarkan manusia untuk menemukan keberkahan dalam berinteraksi dengan al-qur'an. Melalui konsep al-Qur'an Mubarak, manusia dapat memperoleh keberkahan baik melalui pembacaan ayat al-Qur'an secara teks atau melalui dengan pendalaman atau pengkajian terhadap ayat-ayatnya.

\section{SIMPULAN}

Empat ayat dalam al-qur'an yang memperkenalkan istilah keberkahan alqur'an, yaitu surah al-an'ām yakni ayat 92 dan 155, satu ayat pada surah al-Anbiyā' yaitu ayat 50 dan surah şād yaitu ayat 29 .

Analisis terhadap QS. Sad/38 ayat 29, ternyata memberikan pemahaman secara spesifik bahwa makna berkah adalah terwujudnya secara menetap kebaikan pada sesuatu sehingga dapat memberikan manfaat. Setiap manusia mengharapkan segala yang diusahakannya sedapat mungkin memiliki nilai berkah. Melalui ayat 29 dari surah Sad, tersirat suatu petunjuk bahwa Alquran yang menjadi pedoman atau yang biasa disebut hudan, dapat diraih keberkahan darinya melalui pembacaan ayatayatnya. Secara teologis, Al-qur'an diakui sebagai mukjizat nabi saw. dan tidak ada tandingannya, jauh dari campur tangan manusia dalam mewujudkannya karena Alqur'an memang kalam ilahi. Inilah menjadi satu bukti penguat juga sehingga keberadaan al-qur'an itu menyimpan berkah sebagaimana yang disinyalir oleh beberapa ayat. Disamping keberkahan itu dapat diraih melalui bacaan Al-qur'an, berkah dari al-qur'an juga dapat diraih melalui mendalaman ayat atau kajian secara mendalam terhadap makna-makna ayat atau dengan kata lain tadabbur. 


\section{DAFTAR PUSTAKA}

al-Asfahānĩy, Rāgib. t.th. Mufradāt Fi Garìb al-Qur'ān, Bairut: Dar al-M'rifah.

al-Baqi, Muhammad Fu'ad abd. al-Mu'jam al-Mufahras li Alfaz al-Qur'an al-Karim, Indonesia: Maktabah Dahlan.

al-Biqa'i, Ibrāhim bin 'Umar bin Hasan al-Ribāt bin 'Ali bin Abi Bakr. Nazm alDurar Fĩ Tanāsub al-Āyāt wa al-suwar, Juz VII, dalam al-Maktabah alSyāmilah, http//www. altafsir.com.

Hasanah, Niswatun. (2018). Keberkahan sebagai Formulasi Maslahah dalam Kehidupan (Refleksi Santri di Pesantren), Qiema.

Hasan, Aliah B. Purwakania. (2008). Pengantar Psikologi Kesehatan Islami. Jakarta: Rajawali Pers.

Kusaeri, Ahmad. (2017). Berkah dalam Perspektif Al-Qur'an (Kajian tentang Objek yang mendapat keberkahan), Bachelor's Thesis, UIN Syarif Hidayatullah Jakarta, Fakultas Ushuluddin.

Lajnah min 'Ulamā al-Azhar. t.th. Tafsĩr al-Muntakhib, Juz I, t.t.: Maūqi' al-Tafāsir.

Maya, Abu Aisyah Rahendra. (2017). Perspektif Alqur'an tentang Konsep alTadabbur. Al-Tadabbur: Jurnal Ilmu Al-Qur'an dan Tafsir.

al-Mahāriby, Abū Muhammad 'Abd al-Haq bin Galî̉ bin 'Abd al-Rahmān ibn Tamām ibn 'Atiyah. t.th. Al-Muharrir al-Waĩiz, Juz 2, t.tp: Mauqi' alTafasir.

al-Naisabury, Al-Imam Abi al-Husain Muslim Ibn al-Hajjaj al-Qusyairiy. (1996) Sahih Muslim, Juz XIII, Riyadh: Dar al-Kutub li al-Thaba'ah wa al-Nasyr wa al-Tauzi.

Nugraha, Eva. (2018) Ngalap Berkah Al-qur'an: Dampak membaca Al-Qur'an Bagi Pembacanya. Ilmu Ushuluddin, 2018.

Al-Qurthuby. t.th. al-Jāmi' li Ahkām al-Qur'ān, Juz I, t.t.: Maūqi' al-Tafāsir.

al-Sairwan, Al-Syeikh 'Abd al-'Azĩz. t.th. al-Tibyān bi Syarh mā Ittafaqa 'alaih alSyaikhān al-Bukhāri wa Muslim. Juz II, Bairut: Dār al-Rasyĩd.

Salim, Abd. Muin. Beberapa Aspek Metodologi Tafsir al-Qur'an. Ujung Pandang: Lembaga Studi Kebudayaan Islam, 1990.

Setiawan, M. Nur Kholis. Al-Qur'an Kitab Sastra Terbesar. Yogyakarta: eLSAQ Press, 2006.

Shihab, Quraish. Tafsir al-Mishbah: Pesan, Kesan dan Keserasian Al-Qur'an, Jilid I, Jakarta: Lentera Hati, 2002. 
--------. Tafsir Al-Qur'an Al-Karim: Tafsir atas Surat-surat Pendek Berdasarkan Urutan Turunnya Wahyu. Bandung: Pustaka Hidayah, 1997.

--------. Mukjizat Al-Quran: Di Tinjau dari Aspek Kebahasaan, Isyarat Ilmiah, dan Pemberitaan Gaib. Bandung: Mizan, 1997.

al-Sa'di, Abdurrahman bin Nasir. Taysir al-Karim al-Rahman fi Tafsir al-Kalm alMannan, Juz 1 dalam al-Maktabah al-Syamilah, t.t.:Mu'assasah al-Risalah, 2000.

Tim Penyusun. Kesehatan dalam Perspektif Al-Qur'an. Jakarta: Lajnah Pentashihan Mushaf Al-Qur'an, 2009. 